\title{
"FORMAS SE TORNAM ELOQUENTES NA RELAÇÃO COM O CONTEÚDO - QUE É SOCIAL, POLÍTICO, HISTÓRICO, TUDO AO MESMO TEMPO": ENTREVISTA PROFA. INÁ CAMARGO COSTA ${ }^{1}$
}

\begin{abstract}
A escolha para a entrevista que compõe o dossiê Cultura $\mathcal{E}$ Sociedade: para uma análise cultural materialista não foi fortuita. Ao contrário, pensamos em um nome que corroborasse a linha temática e analítica pretendida. Decidimos então por convidar a Profa. Iná Camargo Costa que não só contribuiria para o debate sobre as questões de fundo que estão na base deste dossiê, mas também trataria de um âmbito da produção cultural não abordado nos ensaios: o teatro. Militante, pesquisadora, professora, dramaturga e livre-docente pela Universidade de São Paulo, Iná Camargo Costa pode ser considerada, hoje, uma das maiores expoentes dos estudos de teatro no Brasil. Autora de livros como A hora do teatro épico no Brasil (1996), Sinta o drama (1998), Panorama do rio vermelho (2001) e Nem uma lágrima: teatro épico em perspectiva dialética (2012), Iná suscita, desde os seus primeiros trabalhos, discussões que façam convergir, inequivocamente, aspectos políticos e estéticos. Seus pressupostos analíticos ancorados na teoria marxiana juntamente com a perspectiva estética herdada do teatro épico de Brecht fazem com que suas análises sejam sempre instigantes e profícuas. Mais do que pesquisadora de teatro, Iná pode ser vista como um dos expoentes raros dentro da universidade que conseguem conciliar aspectos teóricos e práticos, tanto nos trabalhos acadêmicos como também nas possibilidades de ação na sociedade. Não precisamos chegar até as entrelinhas da entrevista com Iná para perceber que a crítica social por si só não basta. A cada resposta provocativa,
\end{abstract}

\footnotetext{
${ }^{1}$ Entrevista concedida às Editoras deste número em junho de 2013.
} 
a entrevistada evidencia que o fundamental é sempre a proposta de transformação política e social, na qual a arte tem - ou deve ter - papel decisivo.

Revista Idéias: De início, gostaríamos que falasse um pouco sobre a sua trajetória política e intelectual, abordando questões como a escolha pelo curso de Filosofia, o primeiro grupo político do qual fez parte, seu ingresso nas artes, especialmente no universo do teatro, e como esses elementos se confluíram ao longo de sua vida. Você destacaria algum grupo político ou teatral mais relevante na sua formação?

Iná Camargo Costa: Quando me decidi a estudar Filosofia, estava no último ano de Letras (em Botucatu) e pretendia ser professora de língua portuguesa na rede estadual. Mas avaliava que ainda não tinha estudado tudo o que precisava para ser boa professora. A disciplina de que mais senti falta foi Lógica, que não se estuda em Letras. Assim, o passo seguinte seria a graduação em Filosofia, para estudar Lógica, Teoria do Conhecimento, Estética, entre outras disciplinas do meu interesse. $\mathrm{O}$ motivo para querer estudar especificamente na USP era político: como entrei na faculdade de Letras em 1970, peguei o pior dos anos de chumbo no movimento estudantil. Por isso em 1973, quando me formei, queria uma segunda chance de participar das lutas dos estudantes contra a ditadura. Por este recorte, passo ao segundo item da sua pergunta: o primeiro grupo político ao qual me integrei, já em 1975, foi a frente estudantil chamada Liberdade e Luta, vinculada à Organização Socialista Internacionalista, uma das muitas tendências da Quarta Internacional. Fiquei vinculada a este grupo até 1980, quando pedi exclusão por discordar da resolução de integrar o movimento que viabilizou o PT.

Meu ingresso nas artes foi pela porta dos fundos: depois de ter tido algumas experiências inesquecíveis com o teatro amador estudantil no final dos anos de 1960, em 1977 passei a integrar um grupo de pesquisa na FFLCH-USP, coordenado pela professora Otília Arantes, no qual assumi a responsabilidade pela área de teatro, da qual nunca mais me afastei: toda a minha pesquisa desde 
então é voltada ao teatro, particularmente à dramaturgia. Graças a isso, em 1988 fui convidada a participar como dramaturgista de um grupo teatral no qual permaneci até 2012, ano em que abandonei toda e qualquer atividade pública.

Não tenho a menor dúvida de que em teatro os grupos que mais influíram na minha formação foram primeiro o Teatro de Arena de São Paulo, seguido do Opinião do Rio e, posteriormente, o Teatro São Pedro e o TAIB. Mais tarde (durante a pesquisa acima referida) descobri também que fora influenciada, indiretamente e sem o saber, pelo CPC da UNE, uma vez que o Opinião reuniu veteranos daquela organização. No plano político, foi o movimento trotskista, ou Quarta Internacional, começando pela OSI.

Revista Idéias: Em relação às questões metodológicas do estudo da cultura, como você entende a análise dos aspectos sociais de uma obra? A análise imanente basta em si mesma? A forma em si carregaria aspectos fundamentais para desvelar a sua totalidade? Ou é necessário levar em conta outros aspectos, como a trajetória do autor, sua condição de classe, o contexto sócio histórico etc?

Iná Camargo Costa: Assim como a análise imanente não basta em si mesma, a forma em si mesma não quer dizer nada. Formas, que são conteúdo sedimentado, se tornam eloquentes na relação com o conteúdo - que é social, político, histórico, tudo ao mesmo tempo. Elas podem servir ao conteúdo ou entrar em diversos tipos de contradição com ele. Se estas contradições forem inconsequentes (isto normalmente acontece quando o artista não sabe o que está fazendo), produzirão obras capengas, problemáticas, malogradas, conservadoras, e assim por diante. Quando o artista deliberadamente busca essas contradições, teremos obras de interesse variado, que vão desde o curioso ou meramente interessante e podem chegar até à condição de obra prima, ou de interesse máximo. Aspectos supostamente exteriores, como contexto social, trajetória do autor e sua condição de classe já fazem parte da própria existência da obra. Contexto social e econômico, porque responde pela simples existência material de 
qualquer obra; trajetória e condição de classe do autor, porque constituem a sua presença subjetiva na obra, que é tão importante quanto qualquer outro material. A crítica tem o dever de verificar como essas coisas se combinam ou não em qualquer obra, da mais vagabunda à mais estimulante.

Revista Idéias: Como você vê a relação entre cultura e sociedade hoje? Ou, numa outra formulação, já que estamos inseridos em um sistema capitalista, como se dá a relação entre cultura e luta de classes? Em sua concepção, como as produções culturais estão implicadas na luta pela transformação social? O papel da arte "engajada" é, sobretudo, o de descortinar a ideologia burguesa ou cabe a ela um papel propositivo e de mobilização?

Iná Camargo Costa: A classe dominante trata de controlar e promover por todas as suas agências (mercado, escolas, Estado) a cultura que é apresentada como de interesse geral. As classes dominadas precisam antes de mais nada lutar pela democratização do acesso aos meios de produção cultural se quiserem viabilizar alguma cultura alternativa à dominante. Quando esta luta se acirra, os dominados se organizam em partidos e movimentos que por sua vez criam suas próprias agências de produção cultural. Foi assim na Alemanha do século XIX com a militância cultural dos socialistas e também na Rússia a partir de Outubro de 1917. Todas as modalidades de arte produzidas neste ambiente de luta são por definição engajadas. E seu papel é auxiliar no processo de mobilização e organização da luta. Quanto à arte engajada entre aspas, deixo o problema para a academia tratar. Não é essa a minha praia.

Revista Idéias: A seu ver existe diferença entre arte engajada e arte panfletária? Quais os limites da instrumentalização da arte à política?

Iná Camargo Costa: Essa é uma diferença que só interessa à academia que, por sinal, não sabe fazer as devidas distinções que propõe por antipatia ao verdadeiro engajamento. Para nós, adeptos 
do engajamento total, uma obra panfletária (em defesa enérgica de alguma causa) é tão importante quanto uma peça que apenas levanta questões, denúncias, etc. Pense num panfleto propriamente dito, com palavras de ordem de apoio a alguma reivindicação e em sua tradução em cartaz, ou poesia, por exemplo. Por que este cartaz ou poema não pode ser considerado arte legítima? Durante a guerra civil na União Soviética, Maiakovsky fazia o tempo todo poemas e cartazes panfletários de extremo valor artístico. Quanto à "instrumentalização" da arte pela política, pelo que ficou dito acima, não vejo nenhum problema, desde que O ARTISTA saiba o que está fazendo, da mesma forma que os artistas da publicidade sabem perfeitamente o que estão fazendo quando usam arte a serviço do mercado ou da política conservadora. Esta resposta esquiva deliberadamente o pressuposto não enunciado da pergunta: a autonomia da arte. Acontece que, para nós, autonomia da arte significa submissão ao mercado. Por isso não quero mais perder tempo com esta discussão.

Revista Idéias: Com base na provocação lançada por Umberto Eco ${ }^{2}$ sobre a existência dos apocalípticos e dos integrados dentro do sistema, você considera possível realizar uma arte crítica dentro do capitalismo? Quais as possibilidades para essa crítica? Como a arte se contrapõe à "sociedade do espetáculo"?

Iná Camargo Costa: Se não considerasse possível, não teria me envolvido com a prática teatral desde 1988. Meu grupo não fez outra coisa durante todo esse tempo. As possibilidades são infinitas e valem para todas as modalidades, do desenho (pense, por exemplo, nas charges do Laerte e do Angeli) ao cinema (Godard, Altman, Woody Allen, Lars Von Trier, Alexander Klug, entre inúmeros outros). A arte é crítica desde quando faz a mais modesta denúncia de aspectos horrendos da vida sob a dominação do capital até a exposição dos próprios mecanismos de funcionamento da

2 ECO, Umberto. Apocalípticos e Integrados. Coleção Debates. São Paulo: Perspectiva, 1979. 
sociedade do espetáculo, como fazem metodicamente os cineastas acima citados. Já a contraposição propriamente dita depende de mais um passo: o engajamento do próprio artista na luta pelo fim da sociedade do espetáculo (que é o nome dado por Debord ao mundo criado após a Segunda Guerra Mundial e também foi chamado de sociedade de consumo ou sociedade administrada, dependendo da família teórica).

Revista Idéias: Como levar a arte ao povo e o povo à arte? Como pensar não só o que concerne às obras culturais em si (seu conteúdo e sua forma potencialmente revolucionários) mas à socialização dos meios de produção cultural? (Pensamos aqui nas colocações de Benjamin em "O autor como produtor"3 ou de Raymond Williams nas conclusões de seu "Cultura e Sociedade"). No Brasil você considera que foram feitos avanços nesse sentido?

Iná Camargo Costa: São inúmeros os avanços, mas ainda não conheço nenhum movimento político que tenha colocado expressamente a palavra de ordem da socialização dos meios de produção cultural. Raymond Williams escreveu um programa reformista completo neste sentido, ainda na década de 60, em Communications ${ }^{5}$, mas seu horizonte era a socialização de todos os meios de produção cultural. O MST já chegou perto disso, ao afirmar que sua luta também é pela democratização do acesso aos meios de comunicação, informação e distribuição cultural.

\footnotetext{
${ }^{3}$ BENJAMIN, Walter. O autor como produtor: conferência pronunciada no Instituto para o Estudo do Fascismo, em 27 de abril de 1934. In: Magia e técnica, arte e política: ensaios sobre literatura histórica da cultura. Trad. Sérgio Paulo Ruanet. São Paulo: Brasiliense, 1994, p. 120-136. (Col. Obras Escolhidas v. 1).

${ }^{4}$ WILLIAMS, Raymond. [1958]. Cultura e sociedade: de Coleridge a Orwell. Trad. Vera Joscelyne. Petrópolis, RJ: Vozes, 2011.

5 WILLIAMS, Raymond. [1962]. Communications. 3.ed. Harmondsworth: Penguin, 1976.
} 
Quanto a levar o povo à arte ou a arte ao povo, tudo depende da disposição de luta dos artistas. Infelizmente, ainda hoje a maioria dos que conheço continua acreditando que o mercado por si só promove essa aproximação...

Revista Idéias: O movimento "Arte contra a barbárie" tornou-se referência na luta contra a mercantilização da cultura no Brasil e obteve importantes conquistas, sendo talvez a mais "visível" a aprovação da Lei de Fomento ao Teatro que viabilizou a existência e o desenvolvimento do trabalho de grupos teatrais que fazem a diferença na cena cultural paulistana. Não obstante, sabe-se que a luta pela sobrevizência não deve ser um fim em si mesmo, que o movimento não pode somente "nadar cachorrinho", meramente buscando não se afogar, como você apontou em uma de suas intervenções. Quais seriam então possíveis ações concretas, no campo do teatro e das artes em geral, no sentido de enfrentar as três frentes de atuação por você apontadas, quais sejam: 1) desmoralizar a indústria cultural;2) disputar os meios de produção cultural;3) promover a luta ideológica contra a concepção de arte burguesa/mercantil? Você é otimista em relação aos rumos dos grupos envolvidos no movimento "Arte contra a barbárie"?

Iná Camargo Costa: O "Arte contra a barbárie" já cumpriu a sua função histórica. Ele mesmo já é história. E aprendi com Augusto Boal que ninguém deve fazer propostas se não estiver disposto a implementá-las pessoalmente. Como estou afastada dessas questões há mais de um ano, não tenho nada mais a dizer sobre o assunto e muito menos posso avaliar o que está acontecendo entre os grupos. Menos ainda poderia fazer qualquer tipo de proposta para eles ou para artistas que nem conheço! Ação concreta quem propõe é movimento, como o Arte contra a barbárie, ou partido. Só pode ser fruto de elaboração coletiva.

Revista Idéias: Especificamente sobre a cena teatral brasileira contemporânea, você poderia fazer um breve mapeamento das divergentes linhas? 
| 120 |

Entrevista

Iná Camargo Costa: Há muitos anos que só acompanho a cena teatral de São Paulo, pois deixei de viajar em 2007. A cena brasileira contemporânea vai literalmente do Oiapoque ao Chuí. Desconfio que hoje ninguém tem condições de fazer esse mapeamento.

Mesmo no caso de São Paulo, também já não posso mapear mais nada: estou afastada dela há um ano e agora só vejo o que me interessa muito, seja porque o trabalho é feito por meus amigos, seja porque o assunto me interessa. E, mesmo no caso dos amigos, o assunto até pode me interessar mas se for, por exemplo, teatro processional (como Barafonda, da Companhia São Jorge que eu adoro), nem vou ver, por indisposição física: detesto caminhar!

Revista Idéias: Qual seria a posição em que se encontra o Teatro Oficina? É um teatro que fala apenas para os seus pares? A sua crítica à forma pela qual Zé Celso conduziu as montagens de "O rei da vela" $e$ "Roda viva" se estende às montagens atuais do grupo Oficina?

Iná Camargo Costa: Pela crítica que fiz principalmente a Roda Viva , dá para imaginar que o trabalho do Oficina não me interessa mais há muito tempo. Por isso, honestamente, não posso dizer nada de relevante sobre ele, a não ser que defendo até à morte o direito do Zé Celso fazer o que bem entender. Assim como o meu de não tomar conhecimento do que ele faz.

Revista Idéias: Há diferença entre teatro engajado e teatro épico? É possível dizer que Sartre, influenciado por Brecht, conseguiu realizar um teatro revolucionário na década de 1950? Pode-se dizer que Sartre ficou com as "mãos sujas" de crítica social?

Iná Camargo Costa: É um erro dizer que Sartre foi influenciado por Brecht! Assim como é um erro dizer que Sartre fez teatro revolucionário! Por outro lado, meu interesse por Sartre é mínimo: não me disponho a desenvolver a questão das "mãos

${ }^{6}$ Cf. COSTA, Iná Camargo. Sinta o drama. São Paulo: Vozes, 1998. 
sujas" nos termos dele. Quanto a teatro engajado e teatro épico, pode-se fazer, apenas para fins de reflexão, uma distinção de caráter meramente lógico. Teatro engajado designa qualquer obra que apresente algum conteúdo de crítica social. Teatro épico é um caso específico de teatro engajado que leva em conta também as técnicas que a crítica social exige, como foco narrativo, abandono da estrutura do drama e assim por diante.

Revista Idéias: O crítico literário Roberto Schwarz no ensaio "Altos e Baixos da atualidade de Brecht"7 afirma que a técnica do distanciamento que se propunha revolucionária no contexto vivido pelo dramaturgo alemão, tem sido apropriada pela indústria cultural. Além disso, o crítico não zêe correspondência entre a linguagem do proletariado berlinense com o do brasileiro, visto as diferentes condições históricas entre os países. Gostaríamos de saber a sua opinião sobre esta questão e se, a seu ver, a técnica do distanciamento - aliás vista como possibilidade revolucionária a Walter Benjamin em contraposição às reflexões adornianas - ainda possui força na contemporaneidade?

Iná Camargo Costa: Minha resposta à questão levantada por Roberto Schwarz está enunciada por extenso num ensaio que se chama "Brecht no cativeiro das forças produtivas". Ele está publicado em Nem uma lágrima ${ }^{8}$, um livro que reúne minhas últimas conversas com os grupos de teatro.

Quanto ao distanciamento, acho que já se perdeu tempo demais com ele: não passa de uma infindável série de técnicas que

têm a função de abrir a boca dos espectadores (para rir) e, quando bem sucedida, abre também a cabeça...

7 Cf. SCHWARZ, Roberto. Altos e baixos da atualidade de Brecht. In.: Seqüências brasileiras. São Paulo: Companhia das Letras, 1999. pp. 113-148.

${ }^{8}$ Cf. COSTA, Iná Camargo. Nem uma lágrima: teatro épico em perspectiva dialética. São Paulo: Expressão Popular, 2012. 
$\mid 122$ |

Entrevista

Revista Idéias: Na peça "Armadilhas Brasileiras" da Cia do Feijão a narrativa épica, "num golpe de cena", se transforma numa outra forma artística, denominada de "grotesca", e que poderia ser entendida como uma paródia ao teatro pós dramático. De forma sintética, esta intervenção teatral coloca um debate candente aos grupos que mantêm uma perspectiva à esquerda: o que fazer diante da atual realidade? Você viu a peça e o que achou? E ainda vêe possibilidades de força da dialética nas manifestações artísticas? Quais seriam? Ou onde ela estaria expressa?

Iná Camargo Costa: Eu não preciso responder à pergunta sobre o que fazer, porque os grupos politizados já o fizeram: puseram todo o seu conhecimento técnico e político a serviço do vitorioso movimento contra o aumento da tarifa de ônibus em São Paulo.

Quanto à peça do Feijão, acho que ela é extremamente fiel às intervenções artísticas e teóricas de Mário de Andrade: demonstra de maneira implacável que o artista que se recusa até mesmo a sonhar com uma revolução imaginária - a que está presente em Café - está condenado a ser escravo da aristocracia - os donos da vida, como dizia Mário, inúmeras vezes referidos na Meditação sobre o Tietê - e a se submeter a seus padrões estéticos falsificados e baixíssimos (exemplificados na cantora lírica Silmara Ponga, do Banquete). Como fanática por Mário de Andrade, só posso dizer que achei a peça do Feijão simplesmente o máximo. Com isso acho que as demais perguntas também ficam respondidas.

Só para não deixar em branco a menção feita à Dialética, não se trata de uma questão de possibilidade artística, forte ou fraca: dialética é a maneira como funciona o pensamento, quer tenhamos consciência disso ou não. Ela se manifesta a cada vez que uma criança de 3 anos identifica e nomeia um objeto; é patrimônio da humanidade! 